\title{
FEATURES OF STRATEGIC ANALYSIS OF ENERGY INDUSTRY ENTERPRISES
}

\section{ОСОБЛИВОСТІ ПРОВЕДЕННЯ СТРАТЕГІЧНОГО АНАЛІЗУ ДІЯЛЬНОСТІ ПІДПРИЕМСТВ ЕНЕРГЕТИЧНОЇ ГАЛУЗІ}

\author{
Kateryna S. Burunsuz \\ kateryna.burunsuz@nuos.edu.ua \\ ORCID: 0000-0001-5778-6663
}

\author{
К. С. Бурунсуз, \\ канд. техн. наук, \\ старший викладач
}

\author{
Admiral Makarov National University of Shipbuilding, Mykolaiv \\ Національний університет кораблебудування імені адмірала Макарова, м. Миколаїв
}

\begin{abstract}
Today insufficient attention is paid to the specifics of the application of strategic tools for energy companies. That is why the existing research needs further development in terms of adapting the methods of strategic analysis and planning to the specifics of energy companies. Existing methods should be aimed at improving the SWOT- and PEST-analysis in modern business conditions. The factors of external and internal environment influencing possibilities of development and reforming of the enterprises of power branch of Ukraine are analyzed in the article. Most Ukrainian energy companies operate in dynamic conditions that need to be clearly assessed to determine their impact on competitiveness. In order for companies to survive in an unstable economy, they must identify challenges and opportunities in the environment, be able to predict their strengths and weaknesses and their impact on development strategy. The main components of SWOT-analysis are defined in the article. The main purpose of SWOT-analysis of energy companies is given. A matrix of SWOT-analysis of enterprises of the energy sector of Ukraine has been developed to summarize the results of the main trends in the strategic development of enterprises in the energy sector. The essence of PEST-analysis as a basis for forecasting trends in the macroenvironment is revealed. It provides data and information to help the enterprises of the energy sector of Ukraine make predictions about new situations and circumstances. The main components of PESTanalysis are given. Political, economic, social and technological factors are considered in detail. The table of PEST-analysis of the energy industry of Ukraine is developed. Factors were assessed using the method of hierarchy analysis to determine their degree of impact on the energy sector. Priority vectors of factors influencing the energy sector are calculated.

Key words: SWOT-analysis; PEST-analysis; identification of factors; competitiveness; method of analysis of hierarchies.
\end{abstract}

Анотація. Сьогодні недостатня увага приділяється особливостям застосування стратегічних інструментів для підприємств енергетичної галузі. Саме тому існуючі дослідження потребують подальшого розвитку в частині адаптації методів стратегічного аналізу та планування до специфіки підприємств енергетичної галузі. Існуючі методики повинні бути направлені на вдосконалення проведення SWOT- та PEST-аналізу в сучасних умовах господарювання. У статті проаналізовано чинники зовнішнього та внутрішнього середовища, що впливають на можливості розвитку і реформування підприємств енергетичної галузі України. Більшість підприємств енергетичної галузі України функціонують у динамічних умовах, які мають бути чітко оцінені для визначення їхнього впливу на конкурентоспроможність. Для того щоб підприємства вижили в умовах нестабільної економіки, вони повинні визначити виклики і можливості в оточуючому середовищі, вміти прогнозувати свої сильні та слабкі сторони і свій вплив на стратегію розвитку. У статті визначено основні складники проведення SWOT-аналізу. Наведено основну мету проведення SWOT-аналізу діяльності енергопідприємств. Розроблено матрицю SWOT-аналізу підприємств енергетичної галузі України для узагальнення результатів основних тенденцій стратегічного розвитку підприємств енергетичного сектору. Розкрито сутність PEST-аналізу як основи прогнозування тенденцій макросередовища. Він надає дані та інформацію, які допомагають підприємствам енергетичного сектору України робити прогнози щодо нових ситуацій та обставин. Наведено основні компоненти проведення PEST-аналізу. Детально розглянуто політичні, економічні, соціальні та технологічні фактори. Розроблено таблицю PEST-аналізу енергетичної галузі України. Проведено оцінювання факторів за допомогою методу аналізу ієрархій для встановлення ступеня їхнього впливу на енергетичну галузь. Розраховано власні вектори факторів впливу на енергетичну галузь.

Ключові слова: SWOT-аналіз; PEST-аналіз; ідентифікація факторів; конкурентоспроможність; метод аналізу ієрархій. 


\section{ПОСТАНОВКА ЗАДАЧІ}

Проблема управління енергетичними підприємствами та комплексами $\epsilon$ актуальною в будь-який час. В умовах глобалізації економічних процесів і систем особливо важливою стає задача вдосконалення існуючих теорій і методологій дослідження стратегічно важливих галузей народного господарства.

Сучасні умови функціонування підприємств зумовлені високим ступенем нестабільності й невизначеності, пов'язаних із ситуацією, що склалася під впливом пандемії COVID-19, яка у свою чергу спричинила світову економічну кризу. У результаті в процесі діяльності енергетичних підприємств їхні власники і керівники змушені адаптуватися до причин, що визвали ці негативні явища, і вживати заходів щодо їх нейтралізації [1].

\section{АНАЛІЗ ОСТАННІХ ДОСЛІДЖЕНЬ І ПУБЛІКАЦІЙ}

Дослідженню питань аналізу впливу факторів зовнішнього середовища на стратегію економічної діяльності підприємств за допомогою різноманітних методів аналізу присвячено наукові праці та публікації багатьох зарубіжних та вітчизняних авторів, таких як І. Ансофф, К. Адамс, М. Портер, А.П. Градов, O.М. Скібіцький, I.I. Мазур, П. Друкер, А.А. Томпсон, М.А. Комаров, Г.В. Савицька та ін. [2].

Аналіз сучасного стану енергетичної галузі, зокрема питання розвитку енергетичних комплексів різного цільового призначення, досить повно відображені у вітчизняних та закордонних наукових публікаціях, зокрема Т.О. Євтухова, В.О. Костюк, О.А. Курносова, А.П. Микитенко, Т.Н. Пек та ін. [3].

Зовнішні фактори, що впливають на діяльність підприємств, іноді піддаються контролю, але в основному такі фактори, як інфляція, безробіття, наслідки економічних криз, $є$ неконтрольованими чи погано контрольованими. 3 метою виявлення впливу основних факторів на економічну стратегію підприємств використовується такі інструменти, як SWOT- та PEST-аналіз.

Особливості SWOT-аналізу як одного з інструментів стратегічного управління підприємствами знайшли відображення в публікаціях зарубіжних та вітчизняних учених та фахівців. Такі вчені, як К.А. Мамонов, Б.Г. Скоков, О.О. Короп, Ю.І. Мізік, зазначають, що в разі застосування SWOT-аналізу можна встановити зв'язки між позитивними і негативними якостями, які властиві підприємству, та зовнішніми загрозами і можливостями [4]. Автори T. Habimana, D. Mutambuka та P. Habinshuti [5] підкреслюють, що SWOT-аналіз - це метод стратегічного планування, що використовується для оцінки сильних сторін, слабкості/обмежень, можливостей і загроз, залучених до проєкту або в підприємницькій діяльності. Він передбачає визначення мети проєкту й ідентифікацію внутрішніх і зовнішніх чинників, які $\epsilon$ сприятливими та несприятливими для досягнення цієї мети. Послідовно вивчається середовище, в якому функціонує фірма, прогнозуються зміни тенденцій, які впливають на прийняття стратегічних рішень.

\section{ВІДОКРЕМЛЕННЯ НЕ ВИРІШЕНИХ РАНІШЕ ЧАСТИН ЗАГАЛЬНОЇ ПРОБЛЕМИ}

Проте натепер недостатню увагу приділено особливостям застосування стратегічних інструментів для аналізу діяльності підприємств енергетичної галузі. Саме тому існуючі дослідження потребують подальшого розвитку в частині адаптації методів стратегічного аналізу та планування до специфіки конкретного підприємства. Існуючі методики повинні бути спрямовано на вдосконалення проведення SWOT- та PEST-аналізу в сучасних умовах господарювання.

\section{МЕТА ДОСЛІДЖЕННЯ}

Метою дослідження $є$ оцінка впливу політичних, економічних, соціальних і технологічних факторів макросередовища енергетичної галузі України на стратегічну діяльність підприємств за допомогою методу аналізу ієрархій.

\section{МЕТОДИ, ОБ'ЄКТ ТА ПРЕДМЕТ ДОСЛІДЖЕННЯ}

У статті застосовано метод SWOT-аналізу для оцінки сильних і слабких сторін підприємств енергетичної галузі, їхніх потенційних можливостей та загроз; метод PEST-аналізу - для ідентифікації та моніторингу факторів макрооточення, які впливають на енергетичну галузь України. Об'єктом дослідження $€$ процеси управління діяльністю підприємств енергетичної галузі. Предметом дослідження виступають моделі та механізми, що визначають господарську діяльність підприємств енергетичної галузі.

\section{ОСНОВНИЙ МАТЕРІАЛ}

Одним із ключових інструментів, що використовується нині під час планування національного сталого розвитку, є SWOT-аналіз, абревіатура якого походить від англійських слів strengths (сильні сторони), weaknesses (слабкі сторони), opportunities (можливості), threats (загрози). SWOT-аналіз бере початок зі сфери управління бізнесом і був прийнятий у 1980-х роках державним управлінням у таких областях, як регіональний розвиток і муніципальне планування. Зокрема, було декілька прикладів успішного застосування SWOT-аналізу в галузях регіонального енергетичного планування та утилізації твердих побутових відходів. Низка європейських країн використовували SWOT-аналіз для вибору опозиційних пріоритетів та забезпечення політичної послідовності у своїх національних стратегіях сталого розвитку. Два основні складники SWOT - це показники внутрішньої ситуації, описані існуючими сильними 
і слабкими сторонами, а також показники зовнішнього середовища [6].

Складники SWOT-аналізу в даному досліджені розроблено із застосуванням таких напрямів [2]: розширення сильних сторін; усунення слабких сторін; використання можливостей; пом'якшення наслідків загроз.

Практично всі підприємства енергетичної галузі України функціонують у динамічних, часто нестабільних умовах, які мають бути чітко оцінені для визначення їхнього впливу на конкурентоспроможність. Для того щоб підприємства вижили в умовах нестабільної економіки, вони повинні визначити виклики і можливості в оточуючому середовищі, вміти прогнозувати свої сильні та слабкі сторони та їх вплив на стратегію розвитку.

Основною метою SWOT-аналізу діяльності енергопідприємства $є$ виявлення конкурентних переваг на основі діагностики бізнес-процесів та визначення основних перспективних шляхів розвитку підприємства в рамках конкретної ринкової ситуації [7].

Під час проведення SWOT-аналізу [7] послідовно вивчають середовище, в якому працює фірма, прогнозують зміни тенденцій, а також включають ці зміни в процес прийняття рішень (рис. 1).

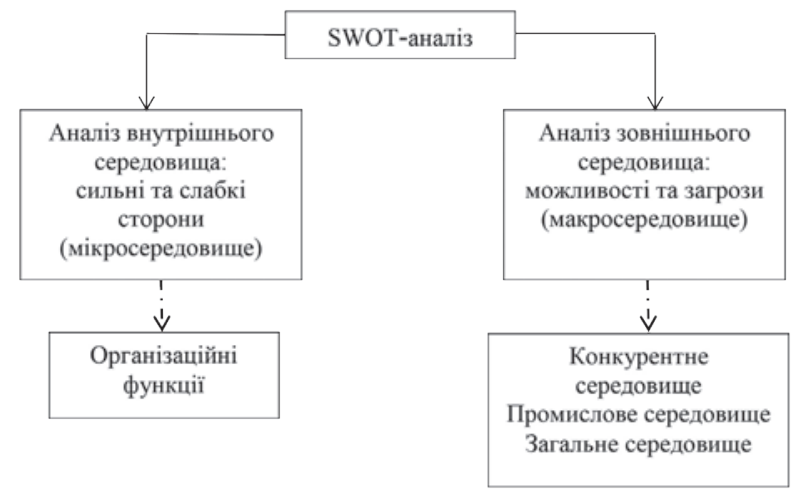

Рис. 1. Складники проведення SWOT-аналізу

У даній роботі матрицю SWOT-аналізу (рис. 1) розроблено для узагальнення результатів основних тенденцій стратегічного розвитку підприємств енергетичного сектору України за даними досліджень [8; 9], а також за прогнозними оцінками деяких експертів у галузі енергетичного машинобудування.

Такий підхід певною мірою дає змогу визначити поточну ситуацію енергетичної галузі в Україні, а також запропонувати ключові напрями і стратегії iii розвитку, спираючись на потенційні можливості та сильні сторони під час усунення слабких сторін і загроз, з якими стикаються підприємства.

Беручи до уваги економічну ситуацію в Україні та оточуючому просторі, представляється доцільним нині використовувати стратегію WT- розвитку та реформування енергетичної галузі.
Під час проведення стратегічного аналізу макрооточення частіше всього використовують метод PESTаналізу [11] (рис. 2).

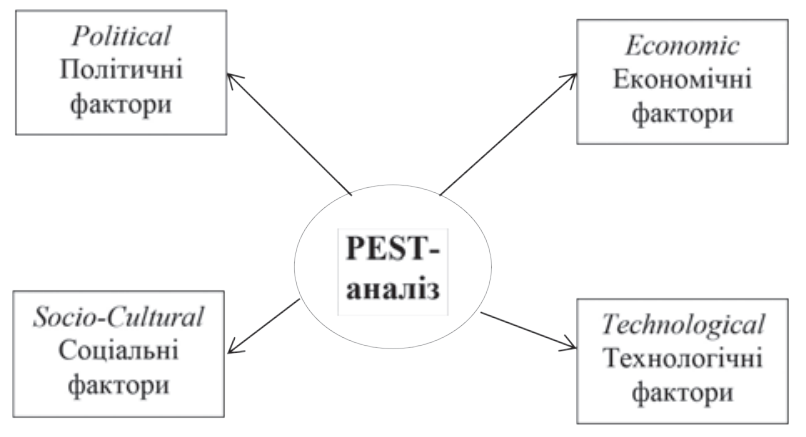

Рис. 2. Складники PEST-аналізу

PEST-аналіз - це передумова стратегічного аналізу ідентифікації середовища, в межах якого компанія функціонує. Він надає дані та інформацію, які допомагають організації робити прогнози щодо нових ситуацій та обставин. PEST-аналіз - це основа або інструмент, який використовується для аналізу та моніторингу факторів макрооточення, що впливають на організацію в цілому чи іiі певний сектор [10]. PEST-аналіз може описувати політичні, економічні, соціальні, технологічні, екологічні та правові граничні умови енергетичного ринку. Насправді, поява нових ефективних технічних рішень потребує насамперед підтримки з боку урядових органів, щоб дати можливість повністю використати інноваційний потенціал підприємства. Крім того, новітні рішення повинні відповідати існуючим законодавчим рамкам. Особлива увага повинна приділятися змісту операційних процесів, ринковим невизначеностям, пов'язаним зі зміною цін на енергоносії, вартості електроенергії, що відпускається різним споживачам, витратам на оплату праці тощо.

Політичні фактори визначають ступінь впливу уряду на економіку загалом чи на певну галузь. До них належать, наприклад, тарифи, законодавчі норми, регулювання конкуренції, податкова політика (податкові ставки та стимули), стабільність уряду та пов'язані з цим зміни, обмеження імпорту на якість та кількість товарів, права інтелектуальної власності (авторські права, патенти), захист прав споживачів та електронна комерція, закони, що регулюють забруднення навколишнього середовища, тощо [10].

Економічні фактори є одними 3 визначальних показників ефективності економіки, які безпосередньо впливають на компанію/галузь і мають резонансні довгострокові наслідки. Вони можуть містити рівень інфляції, процентні ставки, валютні курси, тенденції економічного зростання, зміни в рівні безробіття, зміни в наявному доході на душу населення тощо [10].

Соціальні фактори аналізують соціальне середовище галузі та оцінюють такі детермінанти, 
як культурні тенденції, демографія, аналітика населення. 3 енергетичної точки зору фактори можуть містити структурну організацію громади, рівень взаємодії з громадянами, прийняття чи неприйняття нових технологій, вплив зацікавлених сторін, рівень освіти суспільства, кваліфікацію кадрів, особливос- ті в менталітеті, важливі культурні цінності, зміни в соціальних групах населення [11].

Технологічні чинники відносяться до інновацій у технології, які можуть впливати на діяльність галузі та містять рівні автоматизації наукових досліджень та розробок, а також рівень розвитку технологічної

Таблиця 1. Матриця SWOT-аналізу підприємств енергетичної галузі України

\begin{tabular}{|c|c|c|}
\hline & Сильні сторони (S) & Слабкі сторони (W) \\
\hline $\begin{array}{l}\text { Зовнішні } \\
\text { фактори }\end{array}$ & $\begin{array}{l}\text { - зручне географічне розташування; } \\
\text { - широкий спектр продукції } \\
\text { енергетичної галузі; } \\
\text { - конкурентна ціна вітчизняної } \\
\text { енергетичної продукції в порівнянні } \\
\text { зі світовими цінами; } \\
\text { - відповідно низька вартість робочої } \\
\text { сили; } \\
\text { - добре освічений персонал; } \\
\text { - своя наукова база та глибока } \\
\text { співпраця з національними науково- } \\
\text { дослідними інститутами; } \\
\text { - висока дослідницька спроможність } \\
\text { та відносна гнучкість }\end{array}$ & $\begin{array}{l}\text { - енергоємне виробництво; } \\
\text { - низька диверсифікація експорту; } \\
\text { - високий рівень імпортних компонентів } \\
\text { у високотехнологічних секторах; } \\
\text { - застаріле обладнання та технології, } \\
\text { а також висока амортизація основних } \\
\text { засобів; } \\
\text { - повільне застосування сучасної } \\
\text { технології та повільна модернізація } \\
\text { основних засобів енергопідприємств; } \\
\text { - неефективність управління } \\
\text { (недосконала, складна, ієрархічна } \\
\text { структура управління); } \\
\text { - повільне застосування глобальних } \\
\text { стандартів корпоративного управління }\end{array}$ \\
\hline $\begin{array}{l}\text { Можливості (О) } \\
\text { - технологічні переваги в порівнянні } \\
\text { з традиційними технологіями; } \\
\text { - доступ до європейських ринків; } \\
\text { - значний потенціал національних } \\
\text { технологічних досліджень; } \\
\text { - сильна технічна освіта; } \\
\text { - великий національний ринок; } \\
\text { - міграція енергетичних } \\
\text { компаній ЄС до Східної Європи; } \\
\text { - високий дослідницький потенціал, } \\
\text { особливо через збільшення } \\
\text { фінансування ЄС; } \\
\text { - потреба промисловості в } \\
\text { ефективних відновлювальних } \\
\text { джерелах енергії }\end{array}$ & $\begin{array}{l}\text { Стратегія SO } \\
\text { а) збільшення частки продукції з } \\
\text { високою доданою вартістю; } \\
\text { б) розширення доступу до світових } \\
\text { ринків. } \\
\text { Стратегії SO можуть бути } \\
\text { використані для оптимізації } \\
\text { структури українського експорту } \\
\text { з метою відкриття нових ринків } \\
\text { і розширення існуючих. Сучасні } \\
\text { продукти будуть також користуватися } \\
\text { попитом на місцевих ринках. }\end{array}$ & $\begin{array}{l}\text { Стратегія WO } \\
\text { а) покращення корпоративного } \\
\text { управління; } \\
\text { б) модернізація активів. } \\
\text { Вдосконалення корпоративного } \\
\text { управління, що базується на відповідних } \\
\text { принципах Організації економічного } \\
\text { співробітництва та розвитку (OECP), } \\
\text { є головною метою стратегій WO. } \\
\text { Як пріоритет, краща практика } \\
\text { корпоративного управління повинна бути } \\
\text { впроваджена в публічних компаніях, що } \\
\text { активно торгують на українській біржі. } \\
\text { Посилення підзвітності та покращення } \\
\text { відносин з інвесторами автоматично } \\
\text { сприятимуть зростанню інвестицій у } \\
\text { технологічно розвинені активи. } \\
\end{array}$ \\
\hline $\begin{array}{l}\text { Загрози (Т) } \\
\text { - соціальна уразливість через високу } \\
\text { кількість зайнятих; } \\
\text { - відсутність національної стратегії } \\
\text { або стимулів для розроблення нових } \\
\text { технологій; } \\
\text { - велике значення для економіки за } \\
\text { часткою ВВП; } \\
\text { - зменшення частки в загальному } \\
\text { обсязі експорту протягом останніх } \\
\text { років; } \\
\text { - економічна ситуація в Україні; } \\
\text { - трудова міграція; } \\
\text { - відсутність комплексної системи } \\
\text { інтелектуального захисту прав } \\
\text { власності; } \\
\text { - нестача енергоресурсів; } \\
\text { - відсутність галузевої політики }\end{array}$ & $\begin{array}{l}\text { Стратегія ST } \\
\text { а) збільшення частки продукції з } \\
\text { високою доданою вартістю; } \\
\text { b) підвищення продуктивності в } \\
\text { секторі. } \\
\text { Підвищення продуктивності та } \\
\text { збільшення випуску продукції з } \\
\text { високою доданою вартістю - це } \\
\text { основні кроки, які необхідно } \\
\text { виконувати під час економічного } \\
\text { спаду та зменшення експорту. Ці } \\
\text { стратегії сприятимуть зростанню } \\
\text { експорту та можуть створити основу } \\
\text { для сталого зростання виробництва в } \\
\text { майбутньому. }\end{array}$ & $\begin{array}{l}\text { Стратегія WT } \\
\text { а) покращення корпоративного } \\
\text { управління; } \\
\text { b) підвищення продуктивності в секторі. } \\
\text { Як і у випадку підходу WO } \\
\text { стимулювання українським урядом } \\
\text { поліпшення корпоративного управління } \\
\text { є основою стратегії WT. У поєднанні } 3 \\
\text { урядовими зусиллями, спрямованими на } \\
\text { сприяння підвищенню продуктивності } \\
\text { в секторі, це впливатиме на залучення } \\
\text { іноземних інвесторів і технологій, } \\
\text { підвищення якості продукції, запуск } \\
\text { нових продуктів, вихід на нові ринки. }\end{array}$ \\
\hline
\end{tabular}




\section{ЕКОНОМІКА ТА МЕНЕДЖМЕНТ № 1-2021}

Таблиця 2. PEST-аналіз тенденцій в енергетичній галузі України

\begin{tabular}{|c|c|}
\hline Фактори & Субфактори \\
\hline \multirow{4}{*}{ Політичні } & Зміни в законодавстві щодо регулювання зовнішньоекономічної діяльності підприємств енергетичної галузі \\
\hline & $\begin{array}{l}\text { Підписання економічної частини Угоди про асоціацію між ЄС та Україною, активізація } \\
\text { співробітництва з країнами ЄС }\end{array}$ \\
\hline & Децентралізація влади, адміністративні реформи \\
\hline & Військові дії на сході України та анексія Криму \\
\hline \multirow[t]{7}{*}{ Економічні } & Негативні тенденції в економіці України, спричинені наслідками пандемії COVID-19 \\
\hline & Низька платоспроможність на внутрішньому ринку \\
\hline & Зниження процентних ставок за кредитами в національній валюті \\
\hline & Зменшення частки в загальному обсязі експорту протягом останніх років \\
\hline & Конкурентна ціна вітчизняної енергетичної продукції в порівнянні зі світовими цінами \\
\hline & Падіння доходів Державного бюджету \\
\hline & Зниження споживання електричної енергії у 2020 р. через аномально теплу зиму \\
\hline \multirow[t]{8}{*}{ Соціальні } & Скорочення чисельності працездатного населення \\
\hline & Сильна технічна і технологічна освіта \\
\hline & Соціальна уразливість через високу кількість зайнятих в енергетиці \\
\hline & Комплексна система інтелектуального захисту прав власності, наявність винаходів, патентів на інновації \\
\hline & Трудова міграція \\
\hline & Підвищення рівня знань іноземних мов серед населення \\
\hline & Зростання соціальної напруги в країні, яке спричинено наслідками пандемії COVID-19 \\
\hline & Недостатній рівень оплати праці й мотивації праці в галузі \\
\hline \multirow[t]{7}{*}{ Технологічні } & Наявність географічних, кліматичних та інших умов для сталого розвитку зовнішньоекономічної діяльності \\
\hline & Значний потенціал національних технологічних досліджень \\
\hline & Високий дослідницький потенціал, особливо через збільшення фінансування ЄС передових лабораторій \\
\hline & Потреба промисловості в якісних джерелах енергії \\
\hline & Своя наукова база та глибока співпраця з національними науково-дослідними інститутами \\
\hline & $\begin{array}{l}\text { Профіцит базових генеруючих потужностей атомних електростанцій та дефіцит високоманеврених } \\
\text { генерацій гідроелектростанцій }\end{array}$ \\
\hline & Зростання встановленої потужності об’єктів відновлювальної енергетики за моделлю «зеленого» тарифу \\
\hline
\end{tabular}

обізнаності. Також розглядаються вплив мобільних технологій на розвиток ринкового середовища, інновації в сучасних інформаційних технологіях, що забезпечують ефективну конкуренцію в ринковій сферi [10].

Таблицю PEST-аналізу (табл. 2) розроблено з урахуванням даних $[1 ; 12]$, а також за оцінками експертів у галузі енергетики з метою узагальнення результатів основних тенденцій розвитку енергетичного сектору України.

Після попереднього виявлення чотирьох основних факторів - політичного, економічного, соціального і технологічного спрямування - за допомогою методу аналізу ієрархій виявимо ступінь їхнього впливу на стратегічні напрями діяльності підприємств енергетичної галузі. Таблиця 3 показує відносну вагу розглянутих вище факторів впливу.

Для того щоб інтерпретувати і присвоїти відносні значення кожному з факторів, необхідно нормалізувати представлену вище матрицю порівняння за методикою [3]. У результаті отримуємо так звану нормалізовану матрицю (табл. 4).

Внесок кожного фактору визначається розрахунками, виконаними 3 використанням влас- ного вектора. Власний вектор показує відносну вагу кожного фактору шляхом обчислення середнього арифметичного за всіма факторами. Відзначимо, що сума всіх значень вектора завжди дорівнює 1 (табл. 5).

Таблиця 3. Матриця порівняння для факторів впливу

\begin{tabular}{|c|c|c|c|c|}
\hline & $\begin{array}{c}\text { Полі- } \\
\text { тичні }\end{array}$ & $\begin{array}{c}\text { Еконо- } \\
\text { мічні }\end{array}$ & $\begin{array}{c}\text { Соціа- } \\
\text { льні }\end{array}$ & $\begin{array}{c}\text { Техноло- } \\
\text { гічні }\end{array}$ \\
\hline Політичні & 1 & 2 & 3 & 5 \\
\hline Економічні & $1 / 2$ & 1 & 2 & 2 \\
\hline Соціальні & $1 / 3$ & $1 / 2$ & 1 & 1 \\
\hline Технологічні & $1 / 5$ & $1 / 2$ & 1 & 1 \\
\hline Сума & 2,033 & 4 & 7 & 9 \\
\hline
\end{tabular}

Таблиця 4. Нормалізована матриця порівняння факторів впливу

\begin{tabular}{|c|c|c|c|c|}
\hline & $\begin{array}{c}\text { Полі- } \\
\text { тичні }\end{array}$ & $\begin{array}{c}\text { Еконо- } \\
\text { мічні }\end{array}$ & $\begin{array}{c}\text { Соціа- } \\
\text { льні }\end{array}$ & $\begin{array}{c}\text { Техноло- } \\
\text { гічні }\end{array}$ \\
\hline Політичні & 0,4918 & 0,5000 & 0,4286 & 0,5556 \\
\hline Економічні & 0,2459 & 0,2500 & 0,2857 & 0,2222 \\
\hline Соціальні & 0,1639 & 0,1250 & 0,1429 & 0,1111 \\
\hline Технологічні & 0,0984 & 0,1250 & 0,1429 & 0,1111 \\
\hline
\end{tabular}


Таблиця 5. Розрахунок власних векторів факторів впливу

\begin{tabular}{|c|c|c|}
\hline Критерії & Обчислення & Власний вектор \\
\hline Політичні & $(0,4918+0,500+0,4286+0,5556) / 4=0,494$ & $0,494(49,4 \%)$ \\
\hline Економічні & $(0,2459+0,2500+0,2857+0,2222) / 4=0,2509$ & $0,2509(25,1 \%)$ \\
\hline Соціальні & $(0,1639+0,1250+0,1429+0,1111) / 4=0,1357$ & $0,1357(13,6 \%)$ \\
\hline Технологічні & $(0,0984+0,1250+0,1429+0,1111) / 4=0,1193$ & $0,1193(11,9 \%)$ \\
\hline
\end{tabular}

\section{ОБГОВОРЕННЯ ОТРИМАНИХ РЕЗУЛЬТАТІВ}

Отримані значення власного вектора визначають участь або вагу того чи іншого фактора щодо загального впливу на стратегію діяльності підприємств енергетичної галузі. Згідно з проведеними розрахунками політичні фактори в теперішній ситуації досить великої нестабільності у світі мають найбільшу вагу 49,4\% по відношенню до загального впливу на перспективи розвитку підприємств. Оцінка даного фактора приблизно в 4 рази більше, ніж оцінка за технологічним фактором (вага 11,9\%).

Відзначимо, що в роботі проаналізовано чинники зовнішнього та внутрішнього середовища, що впливають на можливості розвитку та реформування підприємств енергетичної галузі України.

Проведений аналіз показав, що натепер енергетична промисловість є досить перспективною галуззю української економіки, яка вимагає ефективного управління та проведення низки реформ. Темпи зростання енергетичної галузі недостатні, й цілий ряд факторів і умов гальмують подальший ï розвиток. Використання методів стратегічного управління дозволить приймати ефективні рішення й оперативно вирішувати проблеми, пов'язані з негативними факторами, що погіршують темпи розвитку цієї галузі.
Дослідження внутрішнього стану та зовнішнього оточення енергопідприємств є одним із найважливіших засобів формування стратегічної поведінки в довгостроковому періоді.

\section{ВИСНОВКИ}

1. У результаті проведеного дослідження виявлено, проаналізовано та оцінено фактори зовнішнього середовища підприємств енергетичної галузі, що дозволить розробити методики та технології стратегічного аналізу для забезпечення високої ефективності енергокомпаній у процесі реалізації стратегії їх розвитку.

2. Політичні фактори макроотчення мають вагу близько 50\% по відношенню до загального впливу на перспективи розвитку підприємств енергетичної галузі.

3. Подальших досліджень потребують питання розроблення стратегії реформування підприємств енергетичної галузі на основі чинників SWOTта PEST-аналізу. Пропонується використовувати більш широкий спектр методів матричного оцінювання на етапі стратегічного аналізу та застосовувати організаційні принципи з метою забезпечення високої ефективності процесів визначення та реалізації стратегії розвитку підприємств.

\section{REFERENCES}

[1] Saloid, S.V., Labzina, A.A. (2019). Upravlenie ekonomicheskoj bezopasnostyu promyshlennyh predpriyatij v Ukraine [Economic security management of industrial enterprises in Ukraine]. Investyciyi: praktyka ta dosvid [Investments: practice and experience], no. 19, pp. 29-33 [in Russian].

[2] Teslenok, I.M., Korotunova, O.V., Kosenko, Yu.V. (2019). Analiz vplyvu faktoriv zovnishnogo seredovyshha na funkcionuvannya mashynobudivnogo pidpryyemstva [Analysis of the influence of environmental factors on the functioning of the machine-building enterprise]. Ekonomika ta derzhava [Economy and state], no. 1, pp. 78-82 [in Ukrainian].

[3] Burunsuz, K.S. (2018). Vdoskonalennya modelej i mexanizmiv upravlinnya mizhnarodnymy proektamy zi stvorennya plazmoximichnyx elementiv dlya energetychnyh ustanovok [Improvement of models and mechanisms of management of international projects forthe creation of plasma-chemicalelements forpowerplants]:dys....kand.tex.nauk [candidateoftechnical sciences]: 05.13.22. Retrieved from: https://drive.google.com/file/d/1Pk5KwTn-vRYf7EkuM9Wn77BRFZRgBU9A/view [in Ukrainian].

[4] Mamonov, K.A., Skokov, B.G., Korop, O.O., Mizik, Yu.I. (2007). Metody strategichnogo analizu [Methods of strategic analysis]: navch.-metod. posib. [teaching material]. Kharkiv: KNAMG, 208 p. [in Ukrainian].

[5] Habimana T., Mutambuka D., Habinshuti P. (2018). The Contribution of SWOT Analysis in the Competitiveness of Business Enterprises in Rwanda. Journal of Economics, Business and Management, vol. 6, no. 2, pp. 56-60 [in English].

[6] Markovska, N., Taseska, V., Pop-Jordanov, J. (2009). SWOT analyses of the national energy sector for sustainable energy development. Energy, no. 34, pp. 752-756 [in English].

[7] Burunsuz, K.S. (2019). SWOT-analiz pidpryyemstv energetychnoyi galuzi Ukrayiny [SWOT-analysis of the enterprises of the energy industry of Ukraine]: materialy X Mizhnarodnoyi naukovo-texnichnoyi konferenciyi «Innovaciyi v sudnobuduvanni ta okeanotexnici» [materials of the X International scientific and technical conference "Innovations in shipbuilding and ocean engineering"]. Mykolayiv: NUS Publishing, [in Ukrainian].

[8] Naurodski, S., Benc, V., Lacny, M., Lafiuk, I., Valetka, U. (2016). Machine Industry Report. International Visegrad Fund. 86 p. [in English]. 


\section{ЕКОНОМІКА ТА МЕНЕДЖМЕНТ № 1-2021}

[9] Derzhavna sluzhba statystyky Ukrainy (2019) [State Statistics Service of Ukraine]. Retrieved from: http://www.ukrstat.gov.ua/ [in Ukrainian].

[10] PESTLE Analysis of Barriers to Community Energy Development (2020). Retrieved from: http://leco.interreg-npa.eu/subsites/leco/PESTLE_Analysis_LECO_A4_180927-singlepages-final.pdf [in English].

[11] Burunsuz, K.S. (2020). PEST - analiz energetychnoyi galuzi Ukrayiny [PEST - analysis of the energy sector of Ukraine]: materialy XI Mizhnarodnoyi naukovo-texnichnoyi konferenciyi «Innovaciyi v sudnobuduvanni ta okeanotexnici» [materials of the XI International scientific and technical conference "Innovations in shipbuilding and ocean engineering"]. Mykolayiv: NUS Publishing, pp. 200-203 [in Ukrainian].

[12] Yakubiv, V., Hryhoruk, I. (2017). Innovative Methods in Strategic Planning of Foreign Economic Activity of Enterprises. Journal of Vasyl Stefanyk Precarpathian National University, no. 4, pp. 42-49 [in English].

\section{СПИСОК ВИКОРИСТАНОЇ ЛІТЕРАТУРИ}

[1] Салоид, С. В., Лабзина, А. А. (2019). Управление экономической безопасностью промышленных предприятий в Украине. Інвестииії: практика та досвід. № 19. С. 29-33.

[2] Тесленок, І. М., Коротунова, О. В., Косенко, Ю. В. (2019). Аналіз впливу факторів зовнішнього середовища на функціонування машинобудівного підприємства. Економіка та держава. № 1. С. 78-82.

[3] Бурунсуз, К. С. (2018). Вдосконалення моделей і механізмів управління міжнародними проектами зі створення плазмохімічних елементів для енергетичних установок : дис. ... канд. тех. наук : 05.13.22. URL: https://drive.google. com/file/d/1Pk5KwTn-vRYf7EkuM9Wn77BRFZRgBU9A/view

[4] (2007). Методи стратегічного аналізу : навч.-метод. посіб. / К. А. Мамонов, та ін. Харків : ХНАМГ. 208 с.

[5] Habimana T., Mutambuka D., Habinshuti P. (2018). The Contribution of SWOT Analysis in the Competitiveness of Business Enterprises in Rwanda. Journal of Economics, Business and Management. Vol. 6. № 2. P. 56-60.

[6] Markovska, N., Taseska, V., Pop-Jordanov, J. (2009). SWOT analyses of the national energy sector for sustainable energy development. Energy. № 34. P. 752-756.

[7] Бурунсуз, К. С. (2019). SWOT-аналіз підприємств енергетичної галузі України : матеріали X Міжнародної науковотехнічної конференції «Інновації в суднобудуванні та океанотехніці». Миколаїв : Видавництво НУК.

[8] (2016). Machine Industry Report / S. Naurodski et al. International Visegrad Fund. 86 p.

[9] Державна служба статистики України. (2019). URL: http://www.ukrstat.gov.ua/

[10] PESTLE Analysis of Barriers to Community Energy Development. URL: http://leco.interreg-npa.eu/subsites/leco/PESTLE_ Analysis_LECO_A4_180927-singlepages-final.pdf

[11] Бурунсуз, К. С. (2020). PEST-аналіз енергетичної галузі України. Матеріали XI Міжнародної науково-технічної конференції «Інновації в суднобудуванні та океанотехніці». Миколаїв : Видавництво НУК. С. 200-203.

[12] Yakubiv, V., Hryhoruk, I. (2017). Innovative Methods in Strategic Planning of Foreign Economic Activity of Enterprises. Journal of Vasyl Stefanyk Precarpathian National University. № 4. P. 42-49. 